\title{
Feminizm. Tworzenie poprzez zmianę
}

\author{
Aleksandra Derra \\ Uniwersytet Mikołaja Kopernika w Toruniu, \\ Trinity College w Dublinie \\ aldewicz[]umk.pl derraa[]tcd.ie \\ Otrzymano i zaakceptowano: czerwiec 2015; opublikowano: lato 2015.
}

Z wielką przyjemnością, nieukrywaną satysfakcją i ogromną ulgą po wielomiesięcznej pracy oddaję w ręce, głowy i serca Czytelniczek i Czytelników monograficzny tom „Avantu”: Feminizm jako interwencje, w którym przedstawiamy teksty prezentujące interdyscyplinarne badania prowadzone z perspektywy feministycznej. Dobór autorek i autorów nie jest przypadkowy. Zaprosiłam do współpracy badaczki i badaczy szeroko rozumianego akademickiego środowiska toruńskiego (zarówno pracujących w Toruniu, jak i z nim współpracujących), z którymi od dawna działam wspólnie, pisząc i redagując prace naukowe, współorganizując konferencje, wykłady, panele dyskusyjne, spotkania popularyzatorskie, czy też prowadząc podyplomowe studia z zakresu gender $\mathrm{w}$ Instytucie Filozofii $\mathrm{UMK}^{1}$. Z większością z tych osób przyjaźnię się lub „koleżankuję”/koleguję od wielu lat, co ma ogromne znaczenie dla jakości i atmosfery tej współpracy. Cechuje ją otwartość, życzliwość, faktyczne zaciekawienie naukowe, osobiste zaangażowanie, bez których nie da się prowadzić niefasadowej auto-krytyki i krytyki wzajemnej, dokonywać twórczych odkryć ani zajmować się efektywnie działalnością publiczną ${ }^{2}$. Mam nadzieję, że uda się doświadczyć tej atmosfery, czytając poniższe teksty.

Tytuł Feminizm jako interwencje, jakim zdecydowaliśmy się opatrzyć tom, oddaje nie tylko bliskie mi rozumienie feminizmu, ale także spaja heterogeniczne problemy, jakimi zajmują się autorki i autorzy w poszczególnych tekstach, dając określoną wskazówkę interpretacyjną. Podpowiada, by traktować feminizm jako wielowątkowe i zróżnicowane podejście badawcze i krytyczne,

${ }^{1}$ Zob. www.studiagender.umk.pl

${ }^{2}$ Rozumienie krytyki zapożyczam od Donny Haraway. Zob. Haraway, D. 1997. Modest_Witness@Second_Millennium.FemaleMan $\bigodot_{-}$Meets_OncoMouse ${ }^{\mathrm{TM}}$. Feminism and Technoscience. New York, London: Routledge: 151. 
ale nie zapominać, że zasadniczo służy ono prowadzeniu określonych działań/interwencji. Feminizm to teorie i praktyki jednocześnie, a właściwiej rzecz ujmując, wzajemnie na siebie oddziałujące teorio-praktyki.

Prace badawcze w tomie zostały podzielone na trzy części.

W pierwszej z nich Problem płci w nauce / Gender Problem in Science przedstawiamy interwencje dokonywane w namyśle nad nauką, w filozofii nauki oraz poszczególnych teoriach czy praktykach naukowych. Londa Schiebinger $\mathrm{w}$ artykule Czy feminizm zmienil naukę? pokazuje, jakie historycznie zmiany przyniósł feminizm w nauce, zwłaszcza w strukturze instytucji naukowych, sposobie prowadzenia badań, na przykład w medycynie czy prymatologii. W kolejnej swojej pracy Innowacje Genderowe. Studium przypadku: Nauka. Genetyka dookreślania płci biologicznej przekonuje ze swoimi współpracowni(cz)kami, że wrażliwość feministyczna i uwzględnienie czynnika płciowego w nauce przynosi konkretne innowacyjne odkrycia i stymuluje rozwój owocnych badań, czego przykładem jest genetyka i teorie opisujące płeć biologiczną człowieka. W moim artykule The Human Dream of Power. The Portrait of Science as a Conceptual Heritage of the Modern Era dokonuję swoistego przeglądu feministycznego myślenia o tradycji nauki zachodnioeuropejskiej. Przedstawiam idee, jakie przyświecały konstytuowaniu się nowoczesnej nauki, jakie dziedzictwo metaforyki, celów i zadań nauki odziedziczyliśmy w spadku po Baconie czy Galileuszu. Rozważam, czy można je zinterpretować jako „męskie”, zastanawiam się nad metaforami wojennymi używanymi w opisie działań naukowych, problematyzuję ideę postępu; staram się przekonać, jakie korzyści poznawcze daje nam krytyczny, feministycznie zorientowany namysł nad nauką i jej praktykami.

W drugiej części tomu zatytułowanej Subjectivity in-Between. On Femininity and Masculinity znalazły się teksty, które problematyzują podmiotowość. Pokazują, jakie interwencje feminizm wprowadził we współczesne rozumienie męskości i kobiecości w badaniach filozoficznych i literackich. Monika Rogowska-Stangret w artykule Of Other Spaces, of Other Times - Towards Feminist Politics of New Materialism zastanawia się nad powiązaniami między podmiotami, ich naturo-kulturą, otoczeniem biotechnologicznym i innymi aktorami, patrząc na nie z punktu widzenia nowego materializmu feministycznego. Pyta, jak możemy usytuować siebie samych pośród różnorodnych strategii politycznych, wizji czy idei. Analizuje kampanię antygenderową w Polsce jako zjawisko odsłaniające poszczególne warstwy konfliktów polskiego społeczeństwa, na które można spojrzeć z perspektywy polityki squattingu. Marzena Adamiak, rozważając zawiłości teorii Innego Emmanuela Lévinasa w tekście Grey Zone of Subjectivity. Phenomenology of Feminine Body in Emmanuel Lévinas's Thought, nawołuje do podjęcia krytycznej debaty na temat różnicy seksualnej/płciowej. Nie jest to jej zdaniem problem jedynie feministek, ale również ważne wyzwanie teoretyczne, przed jakim stoi cała humanistyka. Pod- 
kreśla, jak istotne dla teorii podmiotowości było wprowadzenie przez Lévinasa metafor związanych z ciałem, przekonuje jednak, że Inności kobiety, opisywanej przez filozofa-mężczyznę, nie powinniśmy traktować jako istoty kobiecości. Zwłaszcza że w jego ujęciu sytuuje się ona w „grey zone” między właściwą podmiotowością a właściwą Innością. Katarzyna Więckowska w tekście An Interregnum: Masculinity and British Fiction at the Turn of the Century przygląda się obrazom i mitologiom męskości, jakie można znaleźć w brytyjskich powieściach końca XX wieku. Pokazuje, że w latach 80. i 90. XX wieku w Wielkiej Brytanii wzrosła ilość badań nad problemem męskości, opublikowano wiele prac, w których męskość była odkrywana, teoretyzowana, konstruowana, demaskowana, ucieleśniania, zmieniana, przeformułowywana etc. W analizowanych tekstach uniwersalizowany jest obraz cierpienia, zagubienia i kryzysu męskości bohaterów mężczyzn, niezależnie od ich narodowości, klasy społecznej, pochodzenia etnicznego. Łączy je wizja „złamanej” kondycji współczesnego mężczyzny. Więckowska przekonuje, że męskość po tym, jak feminizm „rozgościł się” w rozmaitych obszarach kultury, znalazła się w swoistego rodzaju „pomiędzy”: dotychczasowa została zdekonstruowana, nowa jeszcze nie powstała.

W trzeciej części Płeć tego, co społeczne. Niewidzialność, wykluczenie, izolacja prezentujemy teksty z obszaru, na którym niezwłoczne interwencje feministyczne były i są najbardziej konieczne. Mowa tutaj o społeczno-ekonomicznej sytuacji kobiet, zwłaszcza pochodzących z klas nieuprzywilejowanych: robotniczych, biednych, systemowo dysfunkcyjnych. Wydaje się, że postulat wyrażony przez nestorkę feminizmu Simone de Beauvoir w książce Druga płeć z 1949 roku, iż wolności i pełni podmiotowości kobiety będą mogły doświadczać posiadając nie tylko prawa wyborcze, ale także niezależność finansową, jest niezmiennie aktualny. Dorothy Hobson w artykule Gospodynie domowe. Izolacja jako opresja, cytując Karola Marksa przypomina, że aby kapitał mógł się reprodukować w celu utrzymania klasy robotniczej, niezbędny jest popęd samozachowawczy i popęd rozrodczy robotnika. Kapitalista pozostawia tę sprawę robotnikowi, a ściślej kobietom, czego nie zauważał Marks czy ojciec ekonomii Adam $\mathrm{Smith}^{3}$, a co podkreślają badaczki feministyczne, nie tylko w prężnie rozwijającej się ekonomii feministycznej ${ }^{4}$. Hobson przedstawia pracę,

\footnotetext{
${ }^{3}$ Katrine Kilos przypomina, że kiedy Adam Smith zastanawiał się, dzięki komu obiad trafia na jego stół, wymieniał rzeźnika, piekarza, piwowara, wytwórcę świec i wielu innych dowodząc, że kieruje nimi logika handlu wymiennego, własny interes, co właśnie napędza tę wymianę. Nie przyszło mu do głowy, że aby piwowar, piekarz czy rzeźnik mogli pracować, muszą w sferze domowej pracować ich matki, żony czy córki (obszar niewidzialnej płci). Smith nie wspomniał o swojej matce, z którą przez większą część życia mieszkał i która się nim opiekowała. Zob. Kielos, K. 2014. Jedyna płeć. O tym, dlaczego prześladuje cię homo oeconomicus. Warszawa: Czarna Owca: 22, 30.

${ }^{4}$ Badaczki feministyczne od dawna zajmują się tymi problemami na gruncie polskim, choć mam wrażenie, że ich głos jest słabo słyszalny. Zob. chociażby Titkow, A., Duch-Krzystoszek, D., Budrowska, B., red. 2004. Nieodplatna praca kobiet: mity, realia, perspektywy. Warszawa: IFiS PAN;
} 
którą kobiety wykonują w domu jako „niewidzialną” z punktu widzenia kapitału. Ich zamknięcie w sferze domowej to rodzaj izolacji, rozumianej jako jeden ze sposobów doświadczania opresji. Badane prze nią kobiety często ją rozpoznają, ale w swoistym odruchu obronnym nie tylko nie kwestionują, lecz także nie pozwalają sobie zaakceptować uczuć, które się z jej doświadczaniem wiążą. O niewidzialności z nieco innej perspektywy pisze Anna Kola w tekście Odkryć ukryte... Praca socjalna w Polsce z perspektywy women's/gender/feminist studies, w którym pokazuje, że zarówno korzystanie z pomocy socjalnej, badanie jej, jak i zarządzanie taką pomocą zdominowane jest przez kobiety, jednak w namyśle teoretycznym płeć pracy socjalnej nadal pozostaje niewidoczna. Namawia, by „odkryć” feminizm i kwestie płciowe w pracy socjalnej. Przekonuje, że działania pomocowe (i ich teorie) oraz myśl feministyczną można postrzegać przez pryzmat tego, co jest im wspólne. Łączy je ważność, jaką przypisują rozwojowi społecznemu, emancypacji, dobru wspólnemu, odpowiedzialności społecznej za dobrostan ogółu.

Na Omówienia składają się recenzje oraz dział prezentujący Artystki tego numeru. Od pierwszego wydania czasopismo „Avant” wyróżniało się artystycznie wysmakowanymi, interesującymi i intrygującymi okładkami, które były pieczołowicie dobierane, podobnie jak ilustracje umieszczane między poszczególnymi artykułami. Nie inaczej jest w przypadku tomu feministycznego. Jestem niezwykle wdzięczna Artystkom, które zgodziły się zaprezentować w nim swoje prace, wzbogacając jego przekaz wizualnie. Są nimi Bogna Burska, Maess, Dora Chilińska i Urszula Kozak. Informacje na temat ich pracy artystycznej znajdą Państwo wewnątrz numeru. Sztuka jest jedną z tych przestrzeni teorii i praktyk, w której interwencje feministyczne zachodzą chyba „z największym hukiem”. Historyczka sztuki Katarzyna Lewandowska prezentuje ich wycinek w tekście Projekt kuratorsko-artystyczny FEMININE / kobieca kunstkamera, dzięki któremu można poznać prace młodych twórczyń niemieszczące się w dominującym nurcie sztuki. Z kolei Bogna Burska, autorka prac wykorzystanych na okładce tego numeru, w rozmowie z Beatą Jurkiewicz opowiada o tym, jak została artystką, dlaczego tworzy i co kryje się za technologią używania krwi jako materiału malarskiego.

Przedkładany numer nie powstałby bez życzliwego współdziałania wielu entuzjastycznych osób, pracujących pro scientia bono. Ogromne podziękowania należą się Autorkom i Autorom, bez cienia wątpliwości zdecydowanych przyczynić się do jego powstania. Dziękuję redaktorowi naczelnemu Avantu Witoldowi Wachowskiemu za zaproszenie do przygotowania numeru feministycznego, za pomoc w zawiłościach redakcyjnych, zajęcie się sprawą praw autorskich do wskazanych przekładów, za sprawny nadzór nad procesem

Dryjańska, A., Piotrowska, J., red. 2012. Nieodpłatna praca kobiet: różowa strefa gospodarki. Warszawa: Fundacja Feminoteka; Budrowska, B. Nieodpłatna praca kobiet i próby jej wyceny. URL = <http://www.ekologiasztuka.pl/pdf/fe007budrowska.pdf>, 5.06.2015. 
recenzyjnym oraz życzliwe odpowiadanie na dziesiątki moich maili. Dziękuję także: Agacie Koprowicz (Instytut Kultury Polskiej UW), która wzięła na siebie ciężar wielu prac redakcyjnych, w tym - wydatną pomoc w doborze recenzentek; Ewie Bodal za korektę prac anglojęzycznych; Kasi Lewandowskiej za nieodzowną pomoc w doborze artystek, których prace uświetniają ten numer, oraz Milenie Kulasek za merytoryczną korektę tekstów z genetyki.

Czytanie tekstów feministycznych, bez względu na nasze przekonania, może być wielką poznawczą frajdą, której nierzadko towarzyszą dotkliwe pierwszoosobowe przeżycia, wybijając nas z nużącej rutyny codzienności. Utopijni marzyciele i marzycielki, którzy wymyślili emancypację, zawsze mieli nadzieję na to, że ich prace zmieniają światopoglądy, a także dają pierwszy impuls do zmiany najbliższego otoczenia. Namawiam do tego, by feminizm rozumieć jako interwencje, często dotkliwe i niekomfortowe, ale takie, które - napędzane siłą osobistego doświadczenia - mogą tworzyć nowe poprzez wprowadzanie zmian, przekształcać świat na lepszy. Patetycznie i utopijnie to brzmi? Podobnie jak idea biernych i czynnych praw wyborczych kobiet na początku XX wieku czy pomysł, by zarabiały tyle samo co mężczyźni pół wieku później. Historia potrafi zaskakiwać, nawet w swoim najbardziej przygnębiających momentach. Życzę inspirującej lektury i owocnych działań!

Dublin-Toruń 2015

\section{Literatura}

Budrowska, B. Nieodpłatna praca kobiet i próby jej wyceny. URL = <http://www.ekologiasztuka.pl/pdf/fe007budrowska.pdf>, 5.06.2015.

Dryjańska, A., Piotrowska, J., red. 2012. Nieodpłatna praca kobiet: różowa strefa gospodarki. Warszawa: Fundacja Feminoteka.

Haraway, D. 1997. Modest_Witness@Second_Millennium.FemaleMan $\complement_{-}$Meets_OncoMouse $^{\mathrm{TM}}$. Feminism and Technoscience. New York, London: Routledge: 151.

Kielos, K. 2014. Jedyna płeć. O tym, dlaczego prześladuje cię homo oeconomicus. Warszawa: Czarna Owca: 22: 30.

Titkow, A., Duch-Krzystoszek, D., Budrowska, B., red. 2004. Nieodpłatna praca kobiet: mity, realia, perspektywy. Warszawa: IFiS PAN. 